\title{
Local Genius of Enggano People in Handling Antenatal Care
}

\author{
Tamrin Bangsu \\ Lecture in Social Welfare Study Program of Social and Political Science Faculty of Universitas Bengkulu
}

\begin{abstract}
Kesehatan Ibu dan Anak/ KIA (Maternal and child health) problems in Indonesia until 2018 have not been resolved, the birth rate is still relatively high, the infant mortality, maternal mortality, and stillbirth rate are still the highest compared to neighboring countries in Southeast Asia. Various problems becoming the obstacles in eradicating KIA problems at regional levels especially in remote areas are the issue of uneven distribution of health workers, the facilities and infrastructure, lacking transportation facilities, social and economic conditions of the community, local cultural values that hinder, and others. In 2017, the level of utilization of non-medical services for antenatal care and labor still occurred in Enggano Islands, and in the same year, there were also found cases of neonatal, infant, and maternal mortality. This study used a qualitative method with an ethnographic approach. The informants were 13 people chosen by purposive sampling technique. The data collection techniques to collect field data were non-participant observation with direct observation of the local genius of the community on antenatal care service activities, in-depth interviews, and documentation studies. Data analysis has started since the process of classification, data categories between documentation data and the interview data, and observations on the cultural and social components as the forming elements and sources of the local genius of the Enggano community. Based on the results of the research and discussion, it can be concluded that the local genius of the people on Enggano Islands regarding antenatal care is the same as traditional antenatal care activities in other communities in general, namely: massage, traditional herbal ingredients (the herbal ingredients are the same as those in other regions), there were no specific characteristics existed in the research location. The services provided by dukun bayi (traditional birth attendants) as the local potential are the same as those provided by birth attendants in general in other regions. The difference is that some dukun bayi do not want to work side by side with the midwife (traditional birth attendants and midwives in partnership). Also, some birth attendants do not use supernatural methods in handling antenatal and labor; some dukun bayi simply do not use spells, incantations, amulets, or other magical forms to protect pregnant women from evil spirits.
\end{abstract}

DOI: $10.7176 /$ RHSS/10-24-10

Publication date: December $31^{\text {st }} 2020$

\section{Introduction}

KIA problems in Indonesia until 2018 have not been resolved, the birth rate is still relatively high, the infant mortality rate, maternal mortality, and neonatal mortality are still the highest compared to the ones in neighboring countries in Southeast Asia. Various programs have been implemented by the government to solve these problems such as providing midwife services in villages (Village Midwives) in remote areas, providing health infrastructure to sub-districts and even villages, training and improving education for health officers and kader (volunteers). However, those efforts do not give a significant impact on improving KIA in Indonesia. KIA issues are becoming more complex, especially in remote areas, outer islands, and state borders.

Various problems that become the obstacles in eradicating KIA problems at the regional level, especially in remote areas are the issue of uneven distribution of health workers, the facilities and infrastructure, lacking transportation facilities, social and economic conditions of the community, local cultural values that hinder and others. On the other hand, there is also local wisdom that is utilized by the community as a potential for public health treatment such as treating illnesses, antenatal care, and labor assistance.

Enggano Island is one of the sub-districts under the jurisdiction of North Bengkulu Regency. It consists of 6 villages with an area of $400.6 \mathrm{~km} 2$. The villages are located $1 \mathrm{~km}$ to $17 \mathrm{~km}$ away from Puskesmas (Public Health Center) and the Sub-district Office. The population of the Enggano Island is 3.152 consisted of 1712 men and 1,440 women with a sex ratio of 118.89 , the population density is 8 people per square kilometer (source: Profile of Enggano District 2017). Health facilities are very limited, with only 1 Puskesmas available, 1 mobile hospital which has not been operating for the last 5 years to serve the community. Medical staff are also very limited, only 1 doctor (frequently out of service), 8 midwives for 6 villages (some are frequently out of service as being out of the islands), and on daily basis only give health service in Puskesmas. Transportation facilities from village to village or from villages to downtown and Puskesmas are also very limited. Thus, in emergencies, it is very difficult to reach the health services in regional or provincial health centers since the boat service in and out of the islands only serves two times a week. In 2017, the level of utilization of non-medical services for antenatal care and labor still occurred in Enggano Islands, and in the same year, there were also cases of neonatal, infant, and maternal mortality.

From several previous studies, there has been no research that specifically examines the local genius of a 
community related to antenatal care. This study concerns the local genius of the people of Enggano Island (Enggano Sub-district), North Bengkulu Regency. As the outermost and remote island with all its limitations, local genius is of course very important in various aspects of community life, including health services particularly in the handling of antenatal care. The purpose of this research is to know and understand the local genius of the community in antenatal care services in Enggano Island District, North Bengkulu Regency and to describe and analyze how they utilize the local genius in antenatal care services.

The study focuses on the local genius of the community in the Enggano Island Sub-district of North Bengkulu in antenatal care services. As the focus of research, local genius regarding antenatal care services is seen as the local wisdom of the community of Enggano Island based on philosophical values, ethics, methods, and existing traditional habits that are considered good and right, lasting for a long time and is even institutionalized.

\section{Method}

This study used a qualitative method with an ethnographic approach. This approach is considered appropriate as one of the methods in anthropological research to explore the local genius of the community related to the traditional culture which is still practiced from generation to generation as a way to care for and improve the health of pregnant women. The 15 research informants were determined by purposive sampling technique consisting of community leaders; head of Sub-district, the village head, tribe chiefs, traditional affairs leader, birth attendants, midwives, pregnant women, and mothers. These informants could explain and answer the research objectives from the research process carried out. The data collection technique used to collect field data was non-participant observation with direct observation of local genius in antenatal care service activities. Also, in-depth interviews were conducted to explore aspects of local genius that could not be observed through observation and documentary studies to collect secondary data related to antenatal care and local genius. Data analysis has been started right in the field starting from the classification process and data categories from the documentation, interviews, and observations related to the cultural and social components as the formulating elements and sources of the local genius of the Enggano community. The data were analyzed qualitatively through 3 (three) processes: reduction, presentation, and drawing conclusions that were analyzed in an interactive circle analysis.

This kind of analysis mechanism could be carried out because the study performed: (1) domain analysis or making an investigation matrix of the elements of cultural knowledge that is greater than the elements of local genius, the transcript can be seen from the interview notes and field notes, (2) taxonomic analysis or looking for the dominant internal structure and form of opposition by selective observation, (3) component analysis is supported based on the attributes classified according to the group, (4) theme analysis or classifying and connecting the concept of culture as a whole. However, credibility in qualitative research lies in the success of achieving research objectives, exploring social phenomena, and describing the related things to processes and social interactions in various complex activities. The method used to increase the credibility of the study is by using the triangulation method.

\section{Results}

This section describes the data sources or informants of the current study. It also describes the results of the study (local genius) of the community related to antenatal care as a local resource for the Enggano community concerning antenatal care treatment.

\subsection{Descriptions of Informants}

The research was conducted in 6 villages in the Enggano Sub-district, North Bengkulu Regency, Bengkulu Province. Research data collection was carried out on September 9 - September 14 of 2019 by involving researchers and 3 data collectors (enumerators) consisting of students and alumni. The data were collected using observation, interview, and documentation techniques. There were 15 informants consisting of 2 midwives, 4 dukun bayi(s) (traditional birth attendants), 4 pregnant women, 2 infant mothers, and 3 community leaders and traditional affairs leaders. The informants were determined by the purposive sampling technique.

The community culture in a region is also manifested in various public health treatments including how the community provides and utilizes services during pregnancy in their respective regions. Communities in Enggano Sub-district are also practicing their traditional antenatal care. Information was extracted from various informants who were considered competent to provide the necessary information. The following table describes the characteristics of the informants based on age, education, sex, and occupation: 
Table 1. The Characteristics of Informants based on Age, Education, Sex, and Occupation

\begin{tabular}{|c|c|c|c|c|c|c|c|c|c|c|}
\hline \multirow[b]{2}{*}{ No } & \multirow[b]{2}{*}{ Informants } & \multicolumn{2}{|c|}{ Sex } & \multirow[b]{2}{*}{ Age } & \multicolumn{5}{|c|}{ Education } & \multirow[b]{2}{*}{ Occupation } \\
\hline & & $\frac{0}{\sum^{\pi}}$ & 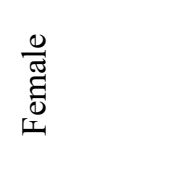 & & 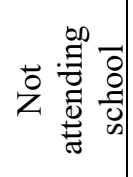 & 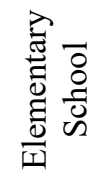 & 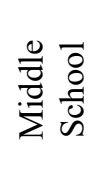 & 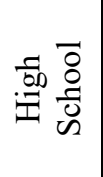 & 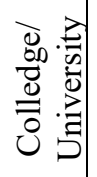 & \\
\hline 1 & RH & $\checkmark$ & & 44 & & & & & & $\begin{array}{l}\text { Village } \\
\text { Head }\end{array}$ \\
\hline 2 & Mwd & $\checkmark$ & & 40 & & & & & & $\begin{array}{l}\text { Civil } \\
\text { Servant } \\
\end{array}$ \\
\hline 3 & Mar & $\mathrm{v}$ & & 54 & & & & & & $\begin{array}{l}\text { Civil } \\
\text { Servant/ } \\
\text { Head of } \\
\text { Sub-district }\end{array}$ \\
\hline 4 & $\mathrm{Hr}$ & $\checkmark$ & & & & & & & & $\begin{array}{l}\text { Pabuki } \\
\text { (Leader of } \\
\text { Tribe } \\
\text { Chiefs) } \\
\end{array}$ \\
\hline 5 & M. R & 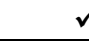 & & 53 & & & & & & Tribe Chief \\
\hline 6 & Ibu Dm & & $\checkmark$ & 54 & & $\sqrt{ }$ & & & & Dukun Bayi \\
\hline 7 & Ibu Ar & & $\checkmark$ & 65 & & $\checkmark$ & & & & Dukun Bayi \\
\hline 8 & Ibu Iy & & $\checkmark$ & 77 & $\checkmark$ & & & & & Dukun Bayi \\
\hline 9 & Ibu Rky & & $\checkmark$ & 56 & & $\checkmark$ & & & & Dukun Bayi \\
\hline 10 & Ibu Bhr & & $\checkmark$ & 63 & & $\checkmark$ & & & & Dukun Bayi \\
\hline 11 & Slv & & $\checkmark$ & 28 & & & & & & \begin{tabular}{|l} 
Civil \\
Servant// \\
Midwife \\
\end{tabular} \\
\hline 12 & Yls & & $\checkmark$ & 34 & & & & & & Midwife \\
\hline 13 & Wl & & $\checkmark \sqrt{ }$ & 26 & & & $\checkmark$ & & & Housewife \\
\hline 14 & $\mathrm{Yl}$ & & $\checkmark \quad \sqrt{ }$ & 28 & & & & & & Housewife \\
\hline 15 & Ibu An & & $\checkmark \quad \sqrt{ }$ & 29 & & & $\checkmark$ & & & Housewife \\
\hline
\end{tabular}

\subsection{Local Genius}

Lack of health resources and transportation to access health services on the island and outside the island makes the community use the potential as their main alternative for immediate medical services and health checks. This condition is not only to cure the illness but also to get services during pregnancy and labor in Enggano Sub-district.

This study focuses on the local genius of the people of Enggano Sub-district related to the use of antenatal care services for pregnant women. The study found several types of services provided by antenatal care providers or dukun bayi(s) and several local treatments. Some of the local geniuses related to nursing skills for pregnant women in Enggano District include::

\subsubsection{Dukun Bayi (Traditional Birth Attendants)}

Dukun bayi is a form of antenatal care service that still exist. The existence of traditional services are related to antenatal care and labor assistance. There is still at least 1 dukun bayi in every village in the Enggano Sub-district. The community needs the services and local expertise of dukun bayi for antenatal care and labor assistance. During the study, it was found that there are 7 dukun bayi(s), but all of them are no longer active in providing labor assistance services and some even refuse to provide antenatal care services.

The refusal to provide these services was related to an appeal from the Puskesmas staff that suggest not to carry out prenatal examinations and labor assistance services. Regarding this appeal, Dukun Bayi Iy (77 years old) stated:

"Since 2015, I am no longer active in providing labor assistance and antenatal care. I was informed by

the Puskesmas midwife that I could no longer massage pregnant women and help with labor. I even got scolded by the Puskesmas staff for examining a pregnant woman, even though I never asked her to come to me for help. Several pregnant women (still) came to ask me to have their pregnancy checked."

The pregnant women in the interviews stated that they still really need the services of dukun bayi to check their pregnancy, especially to know the position of the baby in the womb when there are some discomforts during pregnancy. Dukun bayi can detect the position of the baby in the womb, fix it if the position is abnormal, such as sunsang (footling breech), and even detect whether the delivery can be carried out normally or requires surgery. This opinion was expressed by Mrs. An (29 years) as follows:: 
"In 2018, when I was nine-month-old pregnant, I had my pregnancy checked by Mrs. Iy (dukun bayi in Meok Village). From the results of the examination, the position of my baby's head was not in the right way. She massaged my worm repeatedly to adjust the baby's position but the baby's head shifted from left to right or vice versa when it was supposed to be in the middle. According to Mrs. Iy, my hips are narrow, so I could not give birth normally. When the labor was due, I again asked Mrs. Iy for help, but she ordered me to give birth at the Puskesmas with the midwife. At the same time, Mrs. Iy suggested the midwife to refers me to (hospital) in Bengkulu to have cesarian surgery, but the midwife refused and did not believe Mrs. Iy's words and said that I could give birth normally. After two days at Puskesmas (in Enggano Island), I was eventually referred to Bengkulu, but when I arrived at the hospital in Bengkulu my baby had died in the womb"

This incident was also confirmed by informant Mwd (40 years) as she stated:

"It is true, this incident happened in our family, actually, we are disappointed with the decision of the Puskesmas to delay the patient transfer to the hospital in Bengkulu, but we have let go because everything is God's will.

\subsubsection{Massage}

Massage or combination massages for pregnant women is only practiced by dukun bayi, either at the customer's house or at dukun bayi's house. Pregnant women often asked dukun bayi to check the condition of the fetus or the baby in the womb, then she will touch their belly/ womb with her fingers and palms, by this way she can find out the condition, position of the baby, and the age of the pregnancy. The condition and position of the fetus in the womb will determine if the baby is healthy or a problem occurs. If there is a problem, she will explain to them the condition of the wombs. If she is asked to correct the position or treat the problem, the dukun bayi will massage to fix the fetus position.

Here is the testimony of Mrs. Iy (77 years), dukun bayi in Meok Village:

"I have been working as dukun bayi since 1993 and actively assisted in maternity care and childbirth until 2015. Since 2015 I have almost never helped any deliveries because the midwife at Puskesmas had scolded me for assisting in labor, not only that, whenever pregnant women gave birth with dukun bayi's help, the babies would be troubled to get immunization in Puskesmas later. I feel sorry for them so even though I was asked to help in labor, I refused, and I told them to give birth at the Puskesmas only."

Various pregnancy problems that can be overcome by dukun bayi through massage during pregnancy were stated by a dukun bayi, Mrs. Bhr (63 years):

Problems that can be resolved by dukun bayi and the benefits include: to detect if a woman is pregnant or not, to know the age of the pregnancy, to locate the position of the fetus even though it is still 1 month-old pregnancy, to locate the position of the baby in the womb, to fix the baby's position especially during labor, knowing the baby can be born normally or surgery, and to know the due of the labor.

\subsubsection{Prevention and Cure}

Dukun bayi are still believed and used by some women as antenatal care providers and as birth attendants by some communities. The various services provided by dukun bayi include; being able to carry out antenatal care, finding various childbirth problems, curing diseases, and keeping the pregnancy normal.

To cure and recover the pregnancy, dukun bayi both practice the message and herbal medicine that they formulated personally. In addition to the cure, prevention treatment on pregnancy disorder, labor problems, and after labor problems are also provided by dukun bayi.

3.2.3.1. Prevention

It is believed that the prevention of various disorders or illnesses during pregnancy and labor can be done by pregnant women, whether self-prevention or assisted-prevention provided duku bayi(s). The prevention of various problems can be done through food and daily habits. From early pregnancy until before delivery, several types of food are recommended while others are prohibited for consumption by pregnant women during pregnancy.

Various types of food are recommended for consumption by pregnant women during early pregnancy such as eggs, milk, fish, and meat. Besides, local vegetables such as kepok banana blossom, spinach, and nuts are also recommended. This food is believed to keep the mother healthy, and the fetus can grow and develop properly. Meanwhile, several types of foods are prohibited to consume by pregnant women during early pregnancy including; mutton, durian, jackfruit, and bamboo shoots because those types of food are considered hot and can cause early pregnancy disorders.

When the pregnancy reaches seven months old, several types of food are prohibited including; ripe bananas (because they are sweet), sweetened ices such as iced tea and syrup. Because sugar is believed to cause the baby to grow too big in the womb which will cause problems or difficulty in labor. Apart from bananas and ice during pregnancy, it is not recommended to consume spicy dishes because they can cause the mother and baby to be unhealthy. 
At the age of seven months of pregnancy, a drink of Jatropha leaves begins to be given to pregnant women. The leaves are processed like making tea: dried in the sun and then brewed, brew approximately one sheet of leaf for one glass of hot water, drink it while it is warm. Jatropha leaves are used to strengthen the womb to make sure that the baby does not grow too big. This herbal drink is highly recommended for pregnant women up to ninemonth pregnancy, one glass a day in the afternoon. Also, when the pregnancy reaches eight months old to the labor due day, it is recommended to drink one spoon of coconut oil before going to bed to ease the labor. The coconut is made from coconut milk that is cooked until it turns into oil.

From the pregnancy of seven months until the labor due, pregnant women are not allowed to stay still or just lie down. More physical activities done by pregnant women are effective to prevent the occurrence of abnormalities in the position of the baby in the womb, and they will ease the labor. Pregnant women have to exercise a lot, especially moving the body with a slightly tilted position to direct the baby's head to the right way of labor. Suggested exercise is mopping the floor by hands with a little squat and lowering the head. Apart from the prohibited food and habit, some other habits are not suggested to pregnant women because they are believed to cause problems in the delivery process.

Young coconut water is believed to clean a baby in the womb, so pregnant women before the labor need to drink young coconut water so that the baby is born clean. This habit is still practiced by almost all pregnant women before labor in Enggano Island.

In addition to these various precautions during pregnancy, people still believe that attaching pins or garlic bracelets will prevent various disturbances to pregnant women. Koran and scissors are always put near the newborns to protect them from evil spirits.

Some communities still need dukun bayi(s) for antenatal care and labor assistance, partly because they are more confident in the abilities of a dukun bayi than a midwife while some are in dire need of dukun bayi because no midwives are existing in the village, or the midwife is out of reach when the people need for either pregnant care or labor.

3.2.3.2. Cure

Treatment activities carried out by traditional health care providers as local wisdom of the Enggano community include treatment to overcome problems during pregnancy carried out by dukun bayi(s) and the pregnant women themselves. Pregnancy problems that are usually complained of by pregnant women include complaints of pain in certain parts of the womb, the position of the fetus or the baby is not normal, the fetal movement is excessive or very little, accidents occur by pregnant women such as slips, falls and so on.

If the labor process takes too long, pregnant women are immediately given half-cooked eggs or sweet coffee or garlic to drink to stimulate labor.

Several ways done by dukun bayi(s) to treat or cure pregnancy problems are::

a. Massage

Usually, pregnant women come to the dukun bayi's house by themselves for treatment. They usually come with complaints that the stomach or the womb feels uncomfortable or abnormal due to various problems such as illness after falling or slipping. Massage will be given if the pregnancy is four months old or more. If it is not, massage will not be done because the fetus or womb is still seiran (weak), and massage can be dangerous for the fetus.

b. Herbal Remedy

Various potential herbal remedies in Enggano Island are commonly used by the community related to antenatal care. Some types of these ingredients are only used when needed by pregnant women. The remedy can be recommended or given by dukun bayi(s) or can also be made by pregnant women from generation to generation.

The remedies usually used for pregnant women to refresh the body are: grate turmeric and galangal, squeeze, and add brown sugar and honey. If pregnant women feel nauseous and bloated: boil betel leaf water mixed with a little honey. If pregnant women feel faint and pale: boil some puding merah leaves (graphophyllum hortense Nees.) and add a little brown sugar or honey..

\subsection{Antenatal Care}

The function of Posyandu (Integrated Health Service) is the main service center of pregnancy examinations provided by Puskesmas. Through Posyandu activities every month, pregnancy checks are also held. Each Posyandu also has a "Pregnancy Class". This class for pregnant women is a special class held by Puskesmas staff in Posyandu activities in each village. This class specifically organizes examinations, pregnancy exercises, giving specific vitamin injections, and providing additional food for pregnant women.

Class activities for pregnant women at Posyandu in Kaana Village are also carried out for pregnant women examination activities by midwives at Puskesamas, one of the activities that can be seen in the following figure:

Examinations in pregnancy class at Posyandu are carried out regularly, as stated by the following informant, YI: 
"I routinely follow the Posyandu activities which is held in the village. In addition to being able to check for pregnancy, I am also given various vitamins to maintain my health and my womb. Also, in pregnancy class, I am trained some good movements or positions to prepare for labor. Since I am now nine-month-old pregnant, I always do prenatal check-ups and pregnancy exercises so that I don't have difficulties during the labor..

Apart from pregnancy examinations at Posyandu, some pregnant women still carry out pregnancy examinations at dukun bayi(s), especially to ensure the position of the baby in the womb. This examination is carried out to ensure that the baby's position is in a normal position, if there is an abnormality the dukun bayi(s) can help fix it through massage.

\section{Discussion}

Local genius comes from local and traditional knowledge and management systems (Mitchell et al., 2000: 298). Most of the people of Enggano Island have a fairly good knowledge of what to do to keep their health during pregnancy, the traditional knowledge system of the community is still oriented towards traditional antenatal care services, namely dukun bayi(s). A positive thing related to antenatal care, there is almost neither traditional habit that must be done nor activities such as magic in antenatal care services.

Three out of four total dukun bayi(s) that became informants stated that they did not carry out treatment and medication that used a magical approach. Only one dukun bayi still uses incantations and certain objects to look after and care for pregnant women. This dukun bayi is an immigrant that moved to Enggano Islands. It is in contrast to the results of research conducted by Tamrin Bangsu (2015) that all dukun bayi(s) in Pagar Jati Sub-district use supernatural/ magical approaches and herbal remedies related to antenatal care services. Traditional traditions are still practiced by pregnant women in Pagar Jati Subdistrict during the pregnancy.

The influence of the modern health system approach with all programs and regulations related to health services of antenatal care and labor assistance shifts traditional values to the modern health service system as well as shifts the role of dukun bayi to the role of midwives and doctors. A "regulatory" approach to antenatal care and labor services must be carried out by midwives and must be at a delivery service (Puskesmas or Midwife Clinic). Even though there is a partnership program between a midwife and a dukun bayi, some dukun bayi(s) are reluctant to play the role in the partnership process given the heavier tasks but less income. On the other hand, the community needs traditional services of dukun bayi(s), especially regarding the care, examinations, and preparation to have normal labor; improving the position of the baby, traditional ingredients, and even service as labor attendant. These traditional services can only be obtained from dukun bayi (s) instead of midwives.

In the context of local identity related to the focus of the study, there was no specific identity of the Enggano community in antenatal care services. All activities during pregnancy, whether carried out by antenatal care providers or by pregnant women, are also found in other regions, other tribes, and even on other islands. In the other words, everything that is carried out applies in general. In contrast to Quaritch Wales, anthropologists discuss deeply the notion of local genius which emphasizes aspects of cultural identity or personality identity that exist in a community or society or even nation.

Based on the research findings, the Enggano society does not have a unique identity for antenatal care services. The pattern of traditional antenatal care services for both prevention and treatment also applies in other areas. In fact, this study found the element of rational thinking. Dukun bayi(s) provide services based on hereditary skills and do not use magical/supernatural approaches at all. Beliefs in certain objects that can protect pregnant women from evil spirit disturbances are not practiced by dukun bayi(s).

\section{Conclusion}

Based on the results of the study and discussion, the following conclusions can be drawn:

The local genius of the people of Enggano Island related to antenatal care is the same as that in other communities in general such as massage, traditional herbal remedies (the same type of ingredients as that in other regions), and there is no specific habit or characteristics of the research location. The services provided by dukun bayi(s) are local potential, the same as those provided by dukun bayi(s) in other regions in general. The difference is that some dukun bayi(s) do not want to cooperate with the midwife (Birth Attendance and Midwife in Partnership). Moreover, some dukun bayi(s) do not use supernatural methods in handling antenatal care and labor; some dukun bayi(s) simply do not use spells, incantations, and amulets, or other forms of magic to protect pregnant women from evil spirit disturbance. Based on field data, problems arise due to miscommunication and lack of socialization and training in strengthening partner programs for midwives and dukun bayi(s), both in antenatal care and labor assistance.

Therefore the suggestions based on the result of this study are as follows :

a) The health service providers especially antenatal care and labor services (The Board of Health and Puskesmas), must routinely carry out training and socialization on the program and skills for dukun bayi(s) to re-strengthen the partnership program between midwives and dukun bayi(s) in antenatal care and labor 
assistance. This program is needed to improve the skills of dukun bayi(s) and maximize antenatal care and labor services, especially for pregnant women who still need traditional dukun bayi(s) for both antenatal care and labor assistance using the dukun bayi and midwife partnership.

b) Health resources for midwives and doctors need to be improved in quantity and quality. Ideally, at least 2 general practitioners must be available and a midwife must live in every village in the sub-district.

c) Regional governments must allocate funds to improve infrastructure, especially communication and transportation networks to facilitate the people who need antenatal care and labor services particularly for those that live far away from the health service facility.

\section{References}

Budiono , (2016), Konsep dasar keperawatan, Kemenkes RI, Jakarta, Pusdik SDM Kesehatan BPSDM.

Dalami,Ermawati.(2010), EtikaKeperawatan. Jakarta:Trans Info Media.

Departemen Keseharan Republik Indonesia. (2007). Peraturan Menteri Kesehatan Nomor 938/Menkes/SK/VIII/2007.Tentang Standar Asuhan Kebidanan.Jakarta:Kemenkes RI

Edy Suprabowo, (2006) Praktik Budaya Dalam Kehamilan, Persalinan dan Nifas Pada Suku Dayak Sanggau, Jurnal Kesehatan Masyarakat Nasional, Volume 1 Nomor 3,

Endah Widiastuti, (2016), Konsep Kebidanan dan Etiko Legal Praktek Kebidanan, Jakarta : Pusdik SDM Kesehatan BPSDM Kemenkes RI,

HariningsihW,NurmayawatiD.(2010),BidanEtikaProfesidanHukumKesehatan.Bandung:IrsyadBaitus Salam.

Haryanto, Bangun Sentosa D,(2015), "The Dukuns of Madura: Their Types and Sources of Magical Ability in Perspective of Clifford Geertz and Pierre Bourdieu". Hubs-Asia

Kementerian Kesehatan RI,(2009), Panduan Teknis Kerja Bidan (Edisi Revisi).

Poespowardojo, Soerjanto, (1989) ,Strategi Kebudayaan Suatu pendekatan Filosofis, Jakarta: Gramedia.

Sartini, Sartini; Ahimsa-Putra, Heddy Shri (2017). Redefining The Term of Dukun. Humaniora,29 (1).p. 46-60

Sartini,(2004),Menggali Kearifan Lokal Nusantara Sebagai Kajian Filsafat, Jurnal Filsafat (2)p. 111-120

Sugiyono. (2007), Memahami Penelitian Kualitatif, Bandung: Alfabeta

Tamrin Bangsu, (1995), Hubungan Karakteristik Ibu Dengan Pemilihan Tenaga Penolong Persalinan (Thesis), Jakarta: FKM UI

Tamrin Bangsu, (2015), Selection of Antenatal and Childbirth Care in Rejang Ethnic Group Based on Rational Choice Base, Journal of Research On Humanities and Social Sciences: Volume 5 No 8,p.

Undang-undang Nomor 36 tahun 2009 tentang Kesehatan.

Wahyuni.2009 .Etika Profesi Kebidanan.Yogyakarta:Fitramaya 